\title{
Winter Triticale Mineral Nutrition Elements Ratio Depending on Seeding Rate
}

\author{
Tolstova S.L., Shashkarov L.G., Mefodiev G. A. \\ Department of Agriculture and Plant \\ Chuvash State Agricultural Academy \\ Cheboksary, Russia \\ leonid.shashckarow@yandex.ru
}

\begin{abstract}
The article deals with the maintenance and removal of elements of mineral nutrition by winter triticale plants on gray forest soils of the south-eastern part of the VolgaVyatka zone, depending on the seeding rate and variety. The accumulation of elements of mineral nutrition is significantly influenced by the weather conditions formed during the growing season of winter triticale plants. Winter triticale is very intensively distributed on gray forest soils. In this connection, one of the main tasks is to introduce the most promising varieties into production, adaptive to the southeastern part of the VolgaVyatka zone, which stably form a high yield with high quality of grain, depending on the seeding rate. Research results indicate that winter triticale is demanding on soil fertility. It consumes and alienates a large amount of nutrients from the soil with a good harvest. The removal of mineral nutrition elements also increases, respectively, with an increase in seeding rates.
\end{abstract}

Keywords - Triticale, variety, seeding rate, nitrogen, phosphorus, potassium

\section{INTRODUCTION}

At the present time, grain production remains the most important problem of the crop industry. The growth of productivity of field crops due to the introduction of highquality varieties into production is of particular importance. The leading place is given to the norms of seeding to increase the yield and quality of winter triticale grains among the agrotechnical methods.

The purpose and objectives of research. The purpose of the research was to justify the seeding rates for the planned winter grain yield of triticale of Cornet and Crystal varieties, which are maximally adapted to the conditions of light gray forest light loamy soils of the southeast of the Volga-Vyatka region, allowing the maximum potential of high productivity of varieties to be achieved while ensuring high quality of grain.

The objectives of the research were: to calculate the content, removal and the ratio of the elements of the mineral nutrition of winter triticale plants depending on the seeding rate and variety.

\section{CONDITIONS, MATERIALS AND RESEARCH METHODS}

Field experiments were conducted in the period from 2016 to 2018 on the experimental field UNPTS Campus FSBEI HE "Chuvash State Agricultural Academy".
The experiment was laid on a two-factor scheme. The first factor $\mathrm{A}$ is a variety in two gradations: Cornet and Crystal; the second factor B is the seeding rate in a threefold gradation of 4, 5 and 6 million pcs/ha.

The location of the plots is systematic. Repetition in the experiment is fourfold. The total area of the plot is $200 \mathrm{~m}^{2}$; the harvesting area is $150 \mathrm{~m}^{2}$.

The soil of the experimental area of the gray forest in terms of the granulometric composition of the heavy loam had the following agrochemical characteristics: humus content 5.7-5.8\%; mobile phosphorus - 154-175 and exchangeable potassium 141-155 mg / kg of soil; $\mathrm{pH}$ salt extract 5.2 to 5.3 .

Predecessor - winter wheat. Fertilizers were applied based on the planned yield of $3.0 \mathrm{t} / \mathrm{ha}$, according to the experimental design. Ammonium nitrate, double granulated superphosphate and potassium chloride were used as fertilizers.

Before sowing, the field was cultivated with Smaragd aggregate, sowing was carried out with a $\mathrm{CH}-16$ seeder in an ordinary way. Harvesting was carried out by the combine "SAMPO - 500". The accounts and analyzes in the studies were carried out according to the method of state trials.

\section{ANALYSIS AND DISCUSSION OF RESEARCH RESULTS}

TABLE I. THE CONTENT OF ELEMENTS OF MINERAL NUTRITION IN GRAIN AND STRAW WINTER TRITICALE, $\%, 2016$

\begin{tabular}{|l|l|l|l|l|l|l|}
\hline $\begin{array}{l}\text { Seeding } \\
\text { rate, } \\
\text { million } \\
\text { seeds / ha }\end{array}$ & $\mathbf{N}$ & $\mathbf{P}_{\mathbf{2}} \mathbf{O}_{\mathbf{5}}$ & $\mathbf{K}_{\mathbf{2}} \mathbf{O}$ & $\mathbf{N}$ & $\mathbf{P}_{\mathbf{2}} \mathbf{O}_{\mathbf{5}}$ & $\mathbf{K}_{\mathbf{2}} \mathbf{O}$ \\
\cline { 2 - 7 } & & & & & \\
\hline $\mathbf{6}$ Cornet & \multicolumn{7}{|l|}{ In the straw } \\
\hline $\mathbf{4}$ & 2.42 & 1.09 & 0.53 & 0.54 & 0.42 & 0.85 \\
\hline $\mathbf{5}$ & 2.45 & 1.11 & 0.54 & 0.57 & 0.43 & 0.91 \\
\hline $\mathbf{6}(\mathbf{S t})$ & 2.47 & 1.13 & 0.56 & 0.58 & 0.45 & 0.94 \\
\hline Crystal & 2.36 & 1.09 & 0.53 & 0.50 & 0.42 & 0.73 \\
\hline $\mathbf{4}$ & 2.58 & 1.10 & 0.53 & 0.53 & 0.43 & 0.82 \\
\hline $\mathbf{5}$ & 2.67 & 1.10 & 0.57 & 0.54 & 0.45 & 0.91 \\
\hline $\mathbf{6}(\mathbf{S t})$ &
\end{tabular}

The nitrogen content in the grains varied in the range of $2.42-2.47 \%$ for the Cornet variety and $2.36-2.67 \%$ for the Crystal variety under the conditions of 2016 . The nitrogen content in the straw varied from 0.54 to $0.58 \%$ for the Cornet variety and 0.50 to $0.54 \%$ for the Crystal variety. The phosphorus content in the grains varied from 1.09 to $1.13 \%$ in 
the Cornet variety and 1.09 to $1.10 \%$ in the Crystal variety. The phosphorus content in the straw was $0.42-0.45 \%$ for the Cornet variety and $0.42-0.45 \%$ for the Crystal variety. The content of potassium in the grain varied in the range of 0.53 $0.56 \%$ in the Cornet variety and $0.53-0.57 \%$ in the Crystal variety. There was much more Potassium in the straw than nitrogen and phosphorus $0.73-0.91 \%$ in the Crystal variety and $0.85-0.94 \%$ in the Cornet variety.

TABLE II. THE CONTENT OF ELEMENTS OF MINERAL NUTRITION IN GRAIN AND STRAW WINTER TRITICALE, $\% 2017$

\begin{tabular}{|c|c|c|c|c|c|c|}
\hline \multirow{2}{*}{$\begin{array}{l}\text { Seeding } \\
\text { rate, } \\
\text { million } \\
\text { seeds / ha }\end{array}$} & \multicolumn{3}{|c|}{ In the grain } & \multicolumn{3}{|c|}{ In the straw } \\
\hline & $\mathrm{N}$ & $\mathbf{P}_{2} \mathbf{O}_{5}$ & $\mathrm{~K}_{2} \mathrm{O}$ & $\mathbf{N}$ & $\mathbf{P}_{2} \mathbf{O}_{5}$ & $\mathrm{~K}_{2} \mathrm{O}$ \\
\hline \multicolumn{7}{|l|}{ Cornet } \\
\hline 4 & 2.65 & 1.20 & 0.53 & 0.64 & 0.51 & 0.92 \\
\hline 5 & 2.66 & 1.23 & 0.55 & 0.66 & 0.57 & 0.94 \\
\hline $6(\mathrm{St})$ & 2.89 & 1.26 & 0.57 & 0.70 & 0.59 & 1.00 \\
\hline \multicolumn{7}{|l|}{ Crystal } \\
\hline 4 & 2.82 & 1.30 & 0.53 & 0.78 & 0.44 & 1.05 \\
\hline 5 & 2.83 & 1.32 & 0.55 & 0.78 & 0.44 & 1.05 \\
\hline $6(\mathrm{St})$ & 3.04 & 1.34 & 0.58 & 0.84 & 0.55 & 1.05 \\
\hline
\end{tabular}

The nitrogen content in the grain varied in the range of $2.65-2.89 \%$ in the Cornet variety and $2.82-3.04 \%$ in the Crystal variety, and in straw was contained in the range of $0.64-0.70 \%$ in Cornet and $0.78-0.84 \%$ in Crystal under the conditions of 2017. The phosphorus content in the grain varied in the range of $1.20-1.26 \%$ for the Cornet variety and 1.30 $1.34 \%$ for the Crystal variety. The phosphorus content in the straw was $0.51-0.59 \%$ for the Cornet variety and 0.44 $0.55 \%$ for the Crystal variety. Potassium in the grain was in the range of $0.53-0.57 \%$ in the Cornet variety and 0.53 $0.58 \%$ in the Crystal variety. And in the straw, contained much more potassium than nitrogen and phosphorus of $10.5 \%$ in varieties of Crystal and $0.92-1.00 \%$ in varieties of Cornet.

With an increase in seeding rates from 4 to 6 million seeds / ha, the nitrogen content in the Cornet variety increased from $2.65 \%$ to $2.89 \%$, and in the Crystal variety, $2.82 \%$ to $3.04 \%$. The content of phosphorus and potassium increased in the same pattern.

TABLE III. THE CONTENT OF THE ELEMENTS OF MINERAL NUTRITION IN GRAIN AND STRAW WINTER TRITICALE, \% 2018

\begin{tabular}{|c|c|c|c|c|c|c|}
\hline \multirow{2}{*}{$\begin{array}{l}\text { Seeding } \\
\text { rate, } \\
\text { million } \\
\text { seeds / ha }\end{array}$} & \multicolumn{3}{|c|}{ In the grain } & \multicolumn{3}{|c|}{ In the straw } \\
\hline & $\mathbf{N}$ & $\mathbf{P}_{2} \mathbf{O}_{5}$ & $\mathbf{K}_{2} \mathrm{O}$ & $\mathbf{N}$ & $\mathbf{P}_{2} \mathbf{O}_{5}$ & $\mathrm{~K}_{2} \mathrm{O}$ \\
\hline \multicolumn{7}{|l|}{ Cornet } \\
\hline 4 & 2.36 & 1.08 & 0.52 & 0.52 & 0.41 & 0.85 \\
\hline 5 & 2.42 & 1.10 & 0.55 & 0.56 & 0.43 & 0.90 \\
\hline $6(\mathrm{St})$ & 2.45 & 1.12 & 0.56 & 0.59 & 0.44 & 0.93 \\
\hline \multicolumn{7}{|l|}{ Crystal } \\
\hline 4 & 2.35 & 1.08 & 0.52 & 0.49 & 0.43 & 0.76 \\
\hline 5 & 2.38 & 1.11 & 0.54 & 0.52 & 0.43 & 0.80 \\
\hline $6(\mathrm{St})$ & 2.47 & 1.12 & 0.55 & 0.54 & 0.44 & 0.83 \\
\hline
\end{tabular}

The content of all elements of mineral nutrition was the smallest in the conditions of 2018. The nitrogen content in the grain varied within $2.36-2.45 \%$ in the Cornet variety and
$2.35-2.47 \%$ in the Crystal variety, and in. nitrogen straw was in the range of $0.52-0.59 \%$ in Cornet and $0.49-0.54 \%$ in Crystal. The phosphorus content in the grains varied in the range of $1.08-1.12 \%$ in Cornet and $1.08-1.12 \%$ in Crystal. The phosphorus content in the straw was $0.41-0.44 \%$ in the Cornet variety and $0.43-0.44 \%$ in the Crystal variety. Potassium in the grain was in the range of $0.52-0.56 \%$ in the Cornet variety and $0.52-0.55 \%$ in the Crystal variety. Potassium contained in straw: $0.85-0.93 \%$ in the Cornet variety and $0.76-0.83 \%$ in the Crystal variety.

On average, over the years of the study, the nitrogen content in the grains varied from 2.48 to $2.60 \%$ in Cornet and 2.51 to $2.60 \%$ in Crystal, potassium 0.53 to $0.56 \%$ in Cornet and $0.53-0.53 \%$ for the variety Crystal.

TABLE IV. THE CONTENT OF THE ELEMENTS OF MINERAL NUTRITION IN GRAIN AND STRAW WINTER TRITICALE, \% (2016-2018)

\begin{tabular}{|l|l|l|l|l|l|l|}
\hline $\begin{array}{l}\text { Seeding } \\
\text { rate, } \\
\text { million } \\
\text { seeds / ha }\end{array}$ & $\mathbf{N}$ & $\mathbf{P}_{\mathbf{2}} \mathbf{O}_{\mathbf{5}}$ & $\mathbf{K}_{\mathbf{2}} \mathbf{O}$ & $\mathbf{N}$ & $\mathbf{P}_{\mathbf{2}} \mathbf{O}_{\mathbf{5}}$ & $\mathbf{K}_{\mathbf{2}} \mathbf{O}$ \\
\cline { 2 - 7 } & & & & & \\
\hline Cornet & \multicolumn{7}{l|}{} \\
\hline $\mathbf{4}$ & 2.48 & 1.12 & 0.53 & 0.57 & 0.45 & 0.87 \\
\hline $\mathbf{5}$ & 2.51 & 1.15 & 0.55 & 0.60 & 0.48 & 0.92 \\
\hline $\mathbf{6}(\mathbf{S t})$ & 2.60 & 1.18 & 0.56 & 0.62 & 0.49 & 0.96 \\
\hline $\mathbf{C r y s t a l}$ & 2.51 & 1.16 & 0.53 & 0.56 & 0.43 & 0.85 \\
\hline $\mathbf{4}$ & 2.60 & 1.18 & 0.54 & 0.61 & 0.43 & 0.89 \\
\hline $\mathbf{5}$ & 2.73 & 1.19 & 0.57 & 0.64 & 0.48 & 0.93 \\
\hline $\mathbf{6}(\mathbf{S t})$ &
\end{tabular}

The phosphorus content in the grain varied from 1.12 to $1.18 \%$ in the Cornet variety and 1.16 to $1.18 \%$ in the Crystal variety. The phosphorus content in the straw varied from 0.45 to $0.49 \%$ in the Cornet variety and 0.43 to $0.48 \%$ in the Crystal variety. In the straw, the potassium content was 0.85 $0.93 \%$ in the Crystal variety and $0.87-0.96 \%$ in the Cornet variety.

Weather conditions during the growing season of winter triticale plants had a noticeable effect on the accumulation of mineral nutrition elements. The maximum accumulation of nitrogen and phosphorus in the grains was noted in 2016, as well as nitrogen and potassium in the straw compared with 2017 and 2018. In 2017, the lowest yield was formed for all the years of our research, and per unit of yield in the soilabsorbing complex, a greater amount was accounted for easily hydrolyzed nitrogen, mobile phosphorus and potassium. According to the years of research, the content of potassium in the grain was almost the same, and of all the elements of mineral nutrition, the phosphorus content in the straw was higher under the conditions of 2017.

The content of mineral nutritional elements in winter triticale plants influenced the size of total carry-over (grain + straw), but in our studies, this indicator was largely affected by the seeding rate and winter triticale yield. 
TABLE V. NUTRIENT REMOVAL OF WINTER TRITICALE KG/HA 2016

\begin{tabular}{|l|l|l|l|l|l|l|}
\hline $\begin{array}{l}\text { Seeding } \\
\text { rate, } \\
\text { million } \\
\text { seeds / ha }\end{array}$ & \multicolumn{2}{|l|}{ With the harvest, $\mathbf{k g} / \mathbf{h a}$} & \multicolumn{3}{l|}{ With 1 ton of crop, kg } \\
\cline { 2 - 7 } & $\mathbf{N}$ & $\mathbf{P}_{\mathbf{2}} \mathbf{O}_{\mathbf{5}}$ & $\mathbf{K}_{\mathbf{2}} \mathbf{O}$ & $\mathbf{N}$ & $\mathbf{P}_{\mathbf{2}} \mathbf{O}_{\mathbf{5}}$ & $\mathbf{K}_{\mathbf{2}} \mathbf{O}$ \\
\hline Cornet & 70.25 & 43.87 & 43.31 & 28.07 & 16.43 & 16.59 \\
\hline $\mathbf{4}$ & 70.68 & 44.04 & 43.38 & 28.21 & 16.57 & 17.78 \\
\hline $\mathbf{5}$ & 79.9 & 44.23 & 44.05 & 31.31 & 17.58 & 18.56 \\
\hline $\mathbf{6}$ (St) & 66.59 & 36.97 & 40.68 & 27.06 & 15.93 & 15.75 \\
\hline Crystal & 68.53 & 35.36 & 41.86 & 28.05 & 16.16 & 16.81 \\
\hline $\mathbf{4}$ & 73.74 & 37.27 & 41.96 & 29.53 & 16.43 & 17.49 \\
\hline $\mathbf{5}$ & $\mathbf{6}$
\end{tabular}

The removal of the main nutrients with the yield of grain and straw in the conditions of 2016 at Cornet amounted to $157.4-168.2 \mathrm{~kg} / \mathrm{ha}$, for the Crystal variety $144.2-152.9 \mathrm{~kg} / \mathrm{ha}$ (Table 5).

With an increase in seeding rates from 4 to 6 million seeds/ha, nitrogen removal from the Cornet variety increased from $70.25 \mathrm{~kg} / \mathrm{ha}$ to $79.9 \mathrm{~kg} / \mathrm{ha}$, and in Crystal variety, nitrogen removal increased from $66.59 \mathrm{~kg} / \mathrm{ha}$ to $73.74 \mathrm{~kg} / \mathrm{ha}$. In the Cornet variety, with an increase in the seeding rate from 4 to 6 million seeds / ha, phosphorus removal increased from 43.9 to $44.23 \mathrm{~kg} / \mathrm{ha}$, and in the Crystal variety - from 36.97 to $37.27 \mathrm{~kg} / \mathrm{ha}$.

The removal of potassium in both varieties also increased with an increase in seeding rates from 4 to 6 million seeds/ha. In the Cornet variety there are from $43.31 \mathrm{~kg} / \mathrm{m}$ to $44.05 \mathrm{~kg} / \mathrm{g}$, in the variety Crystal - from $40.68 \mathrm{~kg} / \mathrm{m}$ to $41.96 \mathrm{~kg} / \mathrm{m}$.

TABLE VI. NUTRIENT REMOVAL OF WINTER TRITICALE KG/HA 2017

\begin{tabular}{|c|c|c|c|c|c|c|}
\hline \multirow{2}{*}{$\begin{array}{l}\text { Seeding } \\
\text { rate, } \\
\text { million } \\
\text { seeds / ha }\end{array}$} & \multicolumn{3}{|c|}{ With the harvest, kg/ha } & \multicolumn{3}{|c|}{ With 1 ton of crop, kg } \\
\hline & $\mathrm{N}$ & $\mathrm{P}_{2} \mathrm{O}_{5}$ & $\mathrm{~K}_{2} \mathrm{O}$ & $\mathrm{N}$ & $\mathrm{P}_{2} \mathrm{O}_{5}$ & $\mathrm{~K}_{2} \mathrm{O}$ \\
\hline \multicolumn{7}{|l|}{ Cornet } \\
\hline 4 & 78.89 & 42.19 & 50.65 & 36.98 & 17.44 & 22.31 \\
\hline 5 & 80.65 & 42.82 & 51.10 & 37.82 & 17.75 & 22.46 \\
\hline $6(\mathrm{St})$ & 93.57 & 42.91 & 51.88 & 40.16 & 18.37 & 22.82 \\
\hline \multicolumn{7}{|l|}{ Crystal } \\
\hline 4 & 68.47 & 36.02 & 41.07 & 33.40 & 16.92 & 19.91 \\
\hline 5 & 69.62 & 36.97 & 41.55 & 34.16 & 17.15 & 20.09 \\
\hline $6(\mathrm{St})$ & 74.83 & 38.06 & 42.12 & 35.36 & 17.55 & 20.78 \\
\hline
\end{tabular}

In the conditions of 2017, the removal of basic nutrients with the yield of grain and straw in the Cornet variety was $171.7-188.4 \mathrm{~kg} / \mathrm{ha}$, in the Crystal variety $-145.6-155.0 \mathrm{~kg}$ / ha (Table 6).

With an increase in seeding rates from 4 to 6 million seeds / ha, nitrogen removal from the Cornet variety increased from $78.89 \mathrm{~kg} /$ ha to $93.57 \mathrm{~kg} / \mathrm{ha}$, and in Crystal variety, nitrogen removal increased from $68.47 \mathrm{~kg} /$ ha to $74.83 \mathrm{~kg} / \mathrm{ha}$. In Cornet, the removal of phosphorus from 42.19 to $42.91 \mathrm{~kg}$ / ha, in the variety Crystal - from 36.02 to $38.06 \mathrm{~kg} /$ ha.

Removal of potassium at the Cornet variety is from 50.65 $\mathrm{kg} / \mathrm{ha}$ to $51.88 \mathrm{~kg} / \mathrm{ha}$, and at the Crystal variety - from 41.07 $\mathrm{kg} /$ ha to $42.12 \mathrm{~kg} / \mathrm{ha}$.
TABLE VII. NUTRIENT REMOVAL OF WINTER TRITICALE KG/HA 2018

\begin{tabular}{|l|l|l|l|l|l|l|}
\hline \multirow{2}{*}{$\begin{array}{l}\text { Seeding } \\
\text { rate, } \\
\text { million } \\
\text { seeds / ha }\end{array}$} & $\mathbf{N}$ & $\mathbf{P}_{\mathbf{2}} \mathbf{O}_{\mathbf{5}}$ & $\mathbf{K}_{\mathbf{2}} \mathbf{O}$ & $\mathbf{N}$ & $\mathbf{P}_{\mathbf{2}} \mathbf{O}_{\mathbf{5}}$ & $\mathbf{K}_{\mathbf{2}} \mathbf{O}$ \\
\cline { 2 - 7 } & & & & & & \multicolumn{3}{l|}{} \\
\hline Cornet & 77.10 & 43.50 & 48.23 & 31.84 & 18.53 & 19.26 \\
\hline $\mathbf{4}$ & 79.64 & 44.18 & 48.38 & 38.32 & 18.74 & 19.95 \\
\hline $\mathbf{5}$ & 86.84 & 44.76 & 49.80 & 34.26 & 19.23 & 20.29 \\
\hline $\mathbf{6}$ (St) & 68.87 & 37.01 & 39.94 & 30.49 & 17.77 & 18.01 \\
\hline Crystal & 68.18 & 38.58 & 40.76 & 31.22 & 17.99 & 18.10 \\
\hline $\mathbf{4}$ & 74.82 & 39.77 & 41.39 & 32.68 & 18.31 & 18.16 \\
\hline $\mathbf{5}$ &
\end{tabular}

Under the conditions of 2018, the removal of basic nutrients with the yield of grain and straw in the Cornet variety was $168.8-181.4 \mathrm{~kg} / \mathrm{ha}$, and in the Crystal variety $145.8-155.9 \mathrm{~kg} /$ ha (Table 7).

The removal of nitrogen, phosphorus and potassium with increasing seeding rates from 4 to 6 million seeds / ha increased.

TABLE VIII. NUTRIENT REMOVAL OF WINTER TRITICALE KG/HA (2016-2018)

\begin{tabular}{|c|c|c|c|c|c|c|}
\hline \multirow{2}{*}{$\begin{array}{l}\text { Seeding } \\
\text { rate, } \\
\text { million } \\
\text { seeds / ha }\end{array}$} & \multicolumn{3}{|c|}{ With the harvest, kg/ha } & \multicolumn{3}{|c|}{ With 1 ton of crop, kg } \\
\hline & $\mathbf{N}$ & $\mathbf{P}_{2} \mathbf{O}_{5}$ & $\mathbf{K}_{2} \mathbf{O}$ & $\mathbf{N}$ & $\mathbf{P}_{2} \mathbf{O}_{5}$ & $\mathbf{K}_{2} \mathbf{O}$ \\
\hline \multicolumn{7}{|l|}{ Cornet } \\
\hline 4 & 75.4 & 43.1 & 47.4 & 32.3 & 17.5 & 19.4 \\
\hline 5 & 77.0 & 43.7 & 47.7 & 33.1 & 17.7 & 20.1 \\
\hline $6(\mathrm{St})$ & 86.7 & 43.9 & 48.6 & 35.2 & 18.4 & 20.6 \\
\hline \multicolumn{7}{|l|}{ Crystal } \\
\hline 4 & 66.9 & 36.7 & 40.6 & 30.3 & 16.9 & 17.9 \\
\hline 5 & 68.8 & 36.9 & 41.4 & 31.2 & 17.1 & 18.3 \\
\hline $6(\mathrm{St})$ & 74.5 & 38.4 & 41.8 & 32.5 & 17.4 & 18.8 \\
\hline
\end{tabular}

The total removal of the main nutrients with the yield of grain and straw at Cornet was $165.9-179.2 .9 \mathrm{~kg} / \mathrm{ha}$, and in the Crystal variety - $144.2-154.7 \mathrm{~kg} /$ ha (Table 8).

With an increase in seeding rates from 4 to 6 million seeds / ha, nitrogen removal from Cornet cultivar from $75.4 \mathrm{~kg} / \mathrm{ha}$ to $86.7 \mathrm{~kg} / \mathrm{ha}$, and in Crystal variety, nitrogen removal increased from $66.9 \mathrm{~kg} /$ ha to $74.5 \mathrm{~kg} / \mathrm{ha}$. In the Cornet variety, with an increase in the seeding rate from 4 to 6 million seeds / ha, phosphorus removal increased from 43.1 to $43.9 \mathrm{~kg}$ / ha, and in the Crystal variety, from 36.7 to $38.4 \mathrm{~kg}$ / ha.

The removal of potassium in both varieties also increased with an increase in seeding rates from 4 to 6 million seeds / ha. In the Cornet variety from $47.4 \mathrm{~kg} / \mathrm{ha}$ to $48.6 \mathrm{~kg} / \mathrm{ha}$, in the variety Crystal from $40.6 \mathrm{~kg} /$ ha to $41.8 \mathrm{~kg} / \mathrm{ha}$.

A decrease in seeding rates to 4 million seeds / ha resulted in a decrease in the indicators of the removal of the main elements of mineral nutrition in both varieties (Table 2). In Cornet, the removal of nitrogen decreased by $11.3 \mathrm{~kg} / \mathrm{ha}$, phosphorus - by $0.8 \mathrm{~kg} / \mathrm{ha}$, and potassium - by $1.2 \mathrm{~kg} / \mathrm{ha}$. In the Crystal variety, nitrogen removal decreased by $7.6 \mathrm{~kg} / \mathrm{ha}$, phosphorus - by $1.7 \mathrm{~kg} / \mathrm{ha}$, and potassium - by $1.2 \mathrm{~kg} / \mathrm{ha}$ compared to the standard with a seeding rate of 6 million seeds / ha. 
In the conditions of 2017 , we noted the maximum removal of nitrogen and potassium with the yield of grain and straw in both of our studied varieties. The removal of mineral nutrition elements per 1 ton of grain with the corresponding amount of straw on average during the years of our research was higher in the Cornet variety (Table 2). The maximum removal of mineral nutrition elements per 1 ton of grain with the corresponding amount of straw was characterized by 2017 .

It should be noted that in all the years of the study, the removal of mineral nutrients with the crop and with a single crop in the variants with reduced seeding rates was lower than in the control variant of 6 million seeds / ha [15].

TABLE IX. THE RATIO OF THE MAIN ELEMENTS (2016 - 2018)

\begin{tabular}{|l|l|l|l|l|}
\hline $\begin{array}{l}\text { Seeding rate, } \\
\text { million seeds } \\
\text { ha }\end{array}$ & $\begin{array}{l}\text { NPK, } \\
\mathbf{k g} / \mathbf{h a}\end{array}$ & $\begin{array}{l}\mathbf{N} \% \text { of } \\
\text { total } \\
\text { consump } \\
\text { tion }\end{array}$ & $\begin{array}{l}\mathbf{P}_{2} \mathbf{O}_{\mathbf{5}} \% \text { of total } \\
\text { consumption }\end{array}$ & $\begin{array}{l}\mathbf{K}_{\mathbf{2}} \mathbf{O} \% \text { of } \\
\text { total } \\
\text { consumption }\end{array}$ \\
\hline Cornet & \multicolumn{5}{|l|}{} \\
\hline $\mathbf{4}$ & 165.9 & 45.5 & 25.9 & 28.7 \\
\hline $\mathbf{5}$ & 168.4 & 45.7 & 25.9 & 28.3 \\
\hline $\mathbf{6}$ (St) & 179.2 & 48.4 & 24.5 & 27.1 \\
\hline Crystal & & 28.1 \\
\hline $\mathbf{4}$ & 144.2 & 46.3 & 25.4 & 28.1 \\
\hline $\mathbf{5}$ & 147.1 & 46.7 & 25.1 & 27.0 \\
\hline $\mathbf{6}$ (St) & 154.7 & 48.2 & 24.8 & \\
\hline
\end{tabular}

The ratio of the basic elements of the mineral nutrition of winter triticale is presented in table 3 .

In Cornet variety, the ratio of nutrients was $45.5-48.4 \%$ nitrogen, phosphorus - 24.5-25.9\%, and potassium - 27.1$28.7 \%$. In the Crystal variety, the ratio of the basic elements of mineral nutrition varied within nitrogen 46.3-48.2\%; phosphorus $24.8-25.4 \%$ and potassium - 27.0-28.1\%.

Analysis of the ratio of nutrients in total consumption showed that the increase in seeding rates did not have a significant effect on the fraction of nitrogen and potassium in both Cornet and Crystal variety (Table 3 ). An increase in the seeding rates had an impact on the phosphorus content in the total consumption, and it varied within $1.5 \%$ with an increase in the seeding rate from 5 to 6 million seeds / ha in Cornet and within $0.3 \%$ with an increase in the seeding rate to 5 million seeds / ha and $0.6 \%$ with an increase in the seeding rate of up to 6 million seeds / ha in the Crystal variety.

Thus, the content of nutrients in the grain and straw of winter triticale depends on its varietal characteristics, seeding rates on the value of the formed yield, as well as the weather conditions developing during the growing season.

\section{CONCLUSION}

1) In the cultivation of winter triticale, seeding rates have a significant impact on the content of basic mineral nutrients in grain, the removal of mineral nutrients with the crop, and the ratio of basic mineral nutrients in the total NPK consumption, $\mathrm{kg} / \mathrm{ha}$.

2) The main part of the elements of mineral nutrition as nitrogen and phosphorus is carried with the grain, and potassium - with straw.

\section{References}

[1] Makushev A.E., Shashkarov L.G., "Influence of calculated norms of fertilizers on the NPK content in the main and byproducts of plants and NPK removal by the plant in the conditions of the Chuvash Republic" Agroecological and organizational-economic aspects of creating and efficiently functioning environmentally stable territories materials of the All-Russian scientific-practical conference (Cheboksary, 2017). pp. 7-12.

[2] Voitovich N.V., Kirdin V.F., Polev N.A., Boykov V.A., "Grain farming", 2003, No. 1, pp. 5-7

[3] Vilkov V.S., "New varieties - the most important resource for increasing the productivity of crop production" Nizhny Novgorod Agrarian Journal, 2003, No. 1 (16), pp. 7 - 8

[4] "Actual questions of agronomical science in the 21 st century", In the book under the editorship of V.G. Vasin, Samara, 2004, pp. 433-434.

[5] Zhuchenko A. A., "Scientific priorities for the development of crop production in the XXI century", Bulletin of the Russian Academy of Agricultural Sciences, 2000, No. 2, pp. 9-13.

[6] Zhuchenko A. A., "Adaptation problems in agriculture of the XXI century, Adaptive plant growing (ecological and genetic bases)", Moscow: Publishing house "Agrorus", 2008, pp. 36185.

[7] Zavalin A. A. "Biological products, fertilizers and harvest", Moscow: Publishing house VNIIA, 2005, $302 \mathrm{p}$.

[8] V.P. Zaikin, V.V. Ivenin, "The scientific basis of farming systems of the Volga - Vyatka region tutorial", Nizhniy Novgorod: NGAA, 2003, $288 \mathrm{p}$.

[9] Krasnoshchekov N.V., "Innovative development of agricultural production in Russia", Moscow, 2009, 121 p.

[10] Larionov Yu.S., L.M. Larionova, E.P. Novokreschinov, "Management of adaptability of the variety: theoretical and practical aspects", Chelyabinsk: Publishing house CSAU, 2004, $300 \mathrm{p}$.

[11] Narcissov V. P., "Basics of farming systems of the Gorky region", Gorky, 1982, $318 \mathrm{p}$.

[12] G. S. Posipanov, V. E. Dolgodvorov, B. H. Zherukov, "Crop Farming", Moscow, Kolos, 2006, 612 p.

[13] I.V. Serazhetdinov, M. B., Terekhov, A. V. Gorbunov "The influence of the level of mineral nutrition on the level of various winter triticale varieties", Agriculture, No. 2, 2012, pp.46-48.

[14] I.V. Serazhetdinov, M.B., Terekhov, A. V. Gorbunov "Comparative assessment of winter triticale varieties in the conditions of the south-east of the Volga-Vyatka region", Nizhny Novgorod Agrarian Journal, Nizhniy Novgorod, 2012, p. 149-153.

[15] U.I. Sharafetdinov, M.B Terekhov, M.K. Kayumov "Content and removal of NRK by spring wheat plants" Scientific works of RGAZU, Moscow, 2002, pp. 56-58. 